\title{
DNA Metilasyonu ve Beslenme
}

\author{
DNA Methylation and Nutrition
}

\section{Prof. Dr. Türkan Kutluay Merdol ${ }^{1}$}

Günümüz dünyasında, küreselleşmenin getirdiği artan ticari ilişkiler ve gelişen besin teknolojisi çerçevesinde, beslenme biçimi çok büyük değişimlere sahne olmuş, bu durum bir yandan besin çeşitliliğinde artışa neden olurken, bir yandan da besin dışı maddelerin besine karışmasına ve beraberinde besinde zararlı madde oluşumuna yol açarak kanser gelişiminde ve çeşitliliğinde artışla sonuçlanmıştır. Son yirmi yıllık dönemde yapılan çalışmalar diyet, sigara, alkol, fiziksel aktivite ve vücut ağırlığı yönetimi gibi yaşam tarzı etmenlerinin, kanser nedenlerinin çoğunu oluşturduğunu açıkça ortaya koymuş bulunmaktadır. $\mathrm{Bu}$ oluşumda deoksiribonükleik asit (DNA) metilasyonunun önemli bir rolü olduğu anlaşılmış, diyet ve yaşam tarzı etmenlerinin karsinojenez üzerindeki olumsuz etkilerinin tersine çevrilebilmesinde hangi ögelerin devreye girdiğini açıklamak üzere yapılan epigenetik araştırmalar da artmaya ve pek çok meta-analiz ile, DNA metilasyonunun hangi diyet ve yaşam tarzı belirleyicileri ile değişebildiği konusunda önemli sonuçlar yayınlanmaya başlanmıştır. Bu sonuçların gelecek nesillere daha iyi bir sağlık için önemli ipuçları sağlayacağı açıktır. Beslenme araştırmalarının moleküler zemine taşınması ve besin teknolojisinde yaşanan sistem devrimleri, beslenme bilimi ile uğraşanlara farklı araştırma alanları açmıştır. Besin tüketim kayıtlarının hücre biyolojsi ile bütünleştirilmesi, ileri biyoistatistik, nutrigenetik, epigenomik, transkriptomik, proteomik, metabolik ve moleküler düzeyde değerlendirilmesi, böylece tek nükleotid polimorfizmlerinin (single nucleotide polymorphisms [SNP]) tanınır olması, bunların saptanmasını sağlayan testlerin gelişmesi, yemek düzeni ve egzersiz ilişkisinin çok daha iyi planlanabilmesine yardımcı olacak ve gelecekte günümüze göre çok daha yüksek bir düzeyde bilgi akışı sağlanacaktır. Tüm bu yeni teknolojilerden yararlanmak için bilim insanları uluslararası işbirliği geliştirmeli ve SNP veri tabanı (SNP database [dbSNP]) gibi büyük ve herkese açık erişim veri tabanlarına veri toplanmalıdır. Gelecekteki beslenme araştırmalarının hedefleri, besinlerin vücutla nasıl etkileşime girdikleri konusunda ayrıntılı mekanizmaları anlamak ve böylece özellikle diyetle ilişkili hastalıkları tedavi ederek sağlığı geliştirmektir. Uluslararası işbirliği uygulanacak planların standardizasyonunu (standard operating procedure [SOP]) teşvik edecek ve gelecekteki araştırma projeleri ile toplanan verileri kullanma olanağı sağlayacaktır.

\section{DNA ve Görevleri}

Canlılığımızın sürdürülmesinde, sağlıklı genetik bilgileri koruma ve taşıma çok önemlidir. Bu görevi yapan ve böylece vücudumuzu oluşturan hücrelerin büyümesi ve çoğalması başta olmak üzere pek çok hayati işlevlerde görev alan molekül DNA'dır. DNA, bir kişinin genetik bilgisinin tamamının yer aldığı ve insan vücudunun hemen tüm hücrelerinde (kanda, spermde, deri hücrelerinde, dokularda, organlarda, kaslarda, beyin hücrelerinde, kemikte, dişlerde, saçta, tükürükte, terde, burun sıvısında, tırnaklarda, idrarda, dışkıda vb.) bulunan bir moleküldür. Çok güçlü bir elektron mikroskop altında hücrelerdeki 
kromozom incelendiğinde, kromozomun ipliksi yapı olarak tanımlanan DNA'dan yapıldığı görülür. Her bir gen bir tanım olarak kabul edildiğinde, DNA bu tanımlamaların yazıldığı kimyasal dil olarak tanımlanabilir. Deoksiribonükleik asit, karbon, hidrojen, oksijen, azot ve fosfat atomlarından oluşan nükleotidlerdir. Deoksiribonükleik asidi oluşturan nükleotidler üç bölümden meydana gelirler: 1) baz grubu (adenin-A, timin-A, guanin-G, sitozin-C), 2) şeker (5 karbonlu karbonhidrat) ve 3) fosfat grubu. Birbirine fosfat bağları ile bağlanmış şeker dizilerinde bir şekere bir baz bağlıdır. Bu DNA'nın bir zincirini oluşturur. Yine aynı yapıya sahip olan ikinci DNA dizisi, iki dizi arasında belirli bazlar arasında bulunan hidrojen bağları ile birbirine bağlıdır. Deoksiribonükleik asit bu iki zincirin birbirine sarılarak heliks yapısı oluşturması ile meydana gelir. İnsan hücrelerinde bulunan DNA, yaklaşık üç milyar baz çiftinden oluşur ve yaklaşık bir metre uzunluğundadır. Bu bir metre uzunluğundaki zincir yapı, gözle görülemeyen hücre çekirdeğinde bulunmaktadır. Vücudun her hücresinde bulunan bu zincirler, olduğu gibi durmamakta, gerekli olan bölgeleri enzimler aracıllı̆ı ile açılmakta, taşıdıkları kodlar mesajcı ribonükleik asit (messenger ribonucleic acid [mRNA]) denilen bir başka molekül ile kopyaları çıkarılmakta ve bu kopya vasıtası ile proteinler sentezlenmektedir. Gerekli bölge bu şekilde okunduktan sonra DNA zinciri yine eski haline dönmektedir.

Her organizmada belli sayıda kromozom ve belli uzunlukta DNA bulunur. Örneğin, bir bakteri türü olan Escherichia coli’nin genom büyüklüğü 4.64 megabaz (Mb) iken, buğdayın 17 000, farenin 3300, insanın 3000 Mb'dir. İnsan mantığına göre organizma karmaşıklaştıkça DNA ve gen (baz grupları) sayılarının da çoğalması beklenir. Oysa görüldüğü gibi bir farede ya da buğdayda bile insandan daha uzun DNA bulunmaktadır. Bu da DNA'nın uzun olması ile organizmanın karmaşık olması arasında her zaman doğru orantı olmadığını göstermektedir. Uzun süredir, bilim adamları insan genomunda 50.000140.000 arasında gen olduğunu tahmin etmekteydi. Bu konuda çalışan araştırmacılar, tahmin yöntemlerini değişik kriterleri eldeki son verilere uyguladıklarında gen sayısının 26.000-38.000 arasında olabileceğini belirtmişlerdir. Beklenenden az bulunan gen sayısı ile insan bedenindeki karmaşık yapının nasıl sağlandığı konusunda çalışan bilim insanları insan bedenindeki karmaşıklığın sırrının DNA veya gen sayıları ile değil, DNA'daki kontrol genlerinin davranışlarında olduğunu belirtmektedirler. $\mathrm{Bu}$ da DNA ile ilgili çalışmaların ne denli karmaşık ve zor olduğunun güzel bir göstergesi olsa da, gelişen teknolojinin sağladığı olanaklarla bu karmaşık yapının hastalıkların tedavisi için geliştirilecek yöntemlere önemli ipuçları ortaya koyabileceğini düşündürmektedir.

Deoksiribonükleik asit uzun bir zincir olmasina rağmen zincirdeki bazların sıralanışı belirli bir düzene göre yapılmaktadır. Adenin bazı yalnız timin ile, guanin bazı ise yalnız sitozin ile bağ yapmaktadır. Bunun nedeni adenin ve guanin bazlarının yapısal olarak büyük boylu, timin ve sitozinin ise küçük boylu moleküller olmasıdır. Adenin bazının karşısına timin değil de guanin gelirse, heliks yapısının düzgün ilerlemesi mümkün değildir. Deoksiribonükleik asitte küçük bazlara karşı büyük bazların gelmesiyle aradaki mesafenin her noktada sabit olması sağlanmaktadır. Deoksiribonükleik asidin yapısı bazların bu şekilde art arda sıralanmasıyla uzayıp gider. Hücreler sağlıklı olduklarında ve uygun biçimde büyüyüp geliştiklerinde DNA sürekli olarak aynı biçimde kopyalanıp tekrarlanarak yenilenir. Ancak, bedenin çeşitli zararlı maddelere fazlaca maruz kaldığı durumlarda DNA'nın bu kabiliyetinin hasara uğradığı ve yenilenme süreçlerinin istenen düzeyde gerçekleştirilemediği, bu durumda bedenin özellikle dejeneratif hastalık geliştirme riskinin arttığı ileri sürülmektedir. Deoksiribonükleik asit hasarının geciktirilmesi ya da yavaşlatılması ve hasarın giderilmesi sürecinde beslenmenin, özellikle de vitamin ve mineralden zengin sebze ve meyve tüketiminin çok önemli olduğu bildirilmektedir.

Her bir gen insan vücudundaki belli bir özelliği kontrol eder. Canlının vücut şekli, her organına ait iş bölümü ve bu organların çalışma düzenleri, hücre içinde üretilmesi gereken proteinlerin 
genetik kodları, üretilecek proteinlerin miktar kontrolleri (gen regülasyonu) gibi canlının hayatını devam ettirmesi için gerekli herşey DNA üzerinde planlanmış ve kodlanmıştır. Deoksiribonükleik asitteki şifrelerin deşifre olup organizmayı meydana getirmesi üç aşamada gerçekleşmektedir: 1) DNA'dan RNA sentezi (transkripsiyon), 2) RNA'dan protein sentezi (translasyon), 3) proteini üretilen hücrenin farklılaşması (morfogenez). Bu süreç gen ekspresyonu olarak adlandırılır. Görüldüğü gibi ilk aşama RNA sentezidir. Bu işlem DNA’nın açılmasıyla başlar. Bu işlem için bazlar aralarındaki bağları kopararak DNA'nın çift zincirli yapısını tıpkı bir fermuar gibi açarlar. DNA çözülmeye başladıkça RNA polimeraz adı verilen özel bir protein DNA'nın üzerinde gezerek onu okumaya ve RNA'yı sentezlemeye başlar. Üretilen RNA'nın, DNA'dan tek farkı adenin bazının karşısına timin yerine ' $U$ ' harfiyle gösterilen urasil bazının gelmiş olmasıdır. Üretimi tamamlanan RNA daha sonra DNA üzerinden ayrılarak bir dizi işleme tabi tutulur. Üretilen bu RNA, mRNA olarak isimlendirilir. Mesajcı RNA daha sonra istenen proteinin sentezini oluşturur. Proteini üretilen hücrede morfogenez (programlanmış doku ya da organa dönüşüm süreci) oluşur.

\section{DNA Metilasyonu ve Beslenme}

Dokuların yenilenmesi ve morfogenez sürecinde DNA'da metilasyon yaşanmaktadır. Hidrojen atomunun (H) bir metil grubu ile $\left(\mathrm{CH}_{3}\right)$ yer değiştirmesi şeklinde ifade edilen metilasyon, gen ekspresyonu ile protein ve DNA metabolizması regülasyonunda elzem olan bir süreçtir. Normal hücrelerde gözlenen promotor bölge metilasyonunun, hücre farklılaşmasında dokuya özgügenlerin ekspresyonunu düzenleyerek etkili olduğu düşünülmektedir. Yaşanan bu metilasyonda oluşan bir bozulma organizmanın kansere giden bir sürece girdiğinin göstergesi olarak kullanılmaktadır. Araştırmacıları metilasyon sürecini araştırmaya iten neden, gelişen tümörlerde hipo- ya da hipermetilasyon bulunması olmuştur. Deoksiribonükleik asidin metilasyonu, en önemli epigenetik değişimdir. Bu nedenle son yıllarda yapılan epigenetik çalışmalar DNA metilasyonuna odaklanmıştır. 'Epi', Latince'de 'üstünde' anlamına gelen bir ön ektir. Bu bağlamda 'epigenetik' terimi 'genlerin üstünde' anlamina gelen bir ifade olarak tanımlanabilir.

Epigenetik, DNA dizisinde herhangi bir değişiklik olmamasına karşılık, DNA'da kodlu genetik bilginin açığa çıkmasında meydana gelen değişiklikleri inceleyen bilim alanını tanımlamak için kullanılmaktadır. Bir başka deyişle epigenetik, DNA sekanslarında değişiklik olmaksızın gen ekspresyonundaki değişikliklerin incelenmesini ifade eder. Epigenetik çalışmalarla yaşam biçimi, beslenme alışkanlıkları, sigara ve alkol tüketimi, fiziksel aktivite türü ve derecesi gibi çevresel etmenlerin genlerin aktivitesinidüşürmesiveyayükseltmesiileortayaçıkan rahatsızlıklar incelenmektedir. Epigenetik değişimler geri dönüşümlüdür ve DNA metilasyonunun anahtar süreçlerini, kromotin modifikasyonlarını, nükleozom konumlandırmalarını ve kodlamayan RNA profillerindeki değişikleri içerir. Epigenetik süreçlerdeki bozulmalar, değişmiş gen işlevine ve hücresel neoplastik transformasyona yol açabilir. Geri dönüşümü sağlayan etmenlerin neler olduğu ve nasıl bir etkileşimle bu dönüşümü sağladıkları konusunda yapılan araştırma sayısı gün geçtikçe arttırmakta ve epigenetik değişikliklerin, kanser başlangıcına ve kanserin ilerlemesine katkıda bulunduğu yorumları yapılmaktadır. Epigenetik çalışmalar sadece kanserin biyolojik süreçlerine ışık tutmakla kalmamakta, son teknolojik gelişmelerin desteğiyle, karsinojenez sırasında altta yatan epigenetik değişikliklerin daha iyi anlaşılmasına da olanak sağlayarak tanı, prognoz, risk değerlendirme ve hastalık izlemi için varsayılan epigenetik biyolojik göstergelerin keşfiyle ilgili bilgi akışı sunmaktadır. Bununla birlikte, kanser önleyici bir etki açısından gerekli olan en uygun süre ve doz için daha ileri çalışmalara gereksinim bulunmaktadır. İnsan müdahale çalışmalarında biyoaktif diyet bileşenlerinin moleküler mekanizmaları daha ayrıntılı olarak araştırılmalıdır. Moleküler beslenme ve moleküler epigenetik çalışmalar henüz yolun çok başındadır. 
Deoksiribonükleik asit metilasyonunda etkileri olduğu ileri sürülen ögelerin başında vitamin ve mineraller gelmektedir. Etkileri incelenen vitaminlerin başında da folik asit ve $B_{12}$ vitaminleri gelmektedir. Deoksiribonükleik asit hasarı üzerinde çalışılan bir diğer vitamin E vitaminidir. Fareler üzerinde yapılan araştırmalarda, farelerde toksik madde alımlarından sonra oluşan hasar üzerine $\mathrm{E}$ vitamini verilmesi ile hasarın azaldığı gösterilmiştir. Benzer çalışmalar A vitamini, C vitamini, selenyum, çinko ve kalsiyum üzerinde de yapılmış, bu vitamin ve minerallerden yeterli ve dengeli beslenenlerde kanser insidansının daha düşük olduğu, bunun da DNA hasarına karşı koruyucu özelliklerinden ileri geldiği açıklanmıştır. Ancak bazı araştırıcılar yüksek dozda alındığında, C vitamininin lipit hidroperoksitleri ile birleşerek genotoksinlerin (DNA'yı bozan ajanlar) oluşumuna yol açtığını ileri sürmüştür. Deneysel ortamda gösterildiği söylenen bu etki insan vücudunda gösterilememiştir. C vitamini antioksidan bir vitamin olarak hücre hasarına yol açan serbest radikalleri etkisizleştiren önemli bir vitamindir. Serbest radikaller vücudun her tarafında bulunan ve normal metabolik süreç sonunda ortaya çıkan yan ürünlerdir. Sağlık için serbest radikallerin ortamdan en kısa sürede uzaklaştırılması gereklidir. Vitaminler ve mineraller, bu etki için uygun maddelerdir, ancak yüksek dozlarda alınmaları başka sakıncalar doğurabileceğinden, bahsi geçen vitaminlerin destek olarak değil, sebze ve meyveden zengin ve kişiye özel olarak planlanmış bir diyetle karşılanması konusunda görüş birliği bulunmaktadır.

Vücudun düzenli çalışması için hücrelerin düzenli olarak yenilenmeleri ve onarılmaları gerekmektedir. $\mathrm{Bu}$ süreç için DNA'nın düzenli çalışması esastır. Deoksiribonükleik asidin çalışmasını olumsuz etkileyen etmenlerden biri de kontrolsüz metilasyon işlemidir. Metilasyonun beklenenden az ya da çok olmasinı olumlu ya da olumsuz etkileyen pek çok etmen bulunmaktadır. Olumlu etkileyen etmenlerin başında, bireye özgü olarak hesaplanan, tüm besin ögelerini içeren yeterli, dengeli ve sağlıklı beslenme gelmektedir. Üzerinde en çok çalışılan besin ögeleri B grubu vitaminlerinden folik asit ve $\mathrm{B}_{12}$ vitamini, $\mathrm{A}, \mathrm{C}$ ve E vitaminleri ile minerallerden selenyum, çinko ve kalsiyumdur. Epigenetik alanda yapılan araştırmalar çerçevesinde, bireysel farklılıklara göre beslenme ve diyet planlarının belirlenmesi için bu konularda bilgili ve deneyimli diyetisyene olan gereksinim de gün geçtikçe artmaktadır.

\section{KAYNAKLAR}

1. Baylin SB, Herman JG, Graff JR, Vertino PM, Issa JP. Alterations in DNA methylation: a fundamental aspect of neoplasia. Adv Cancer Res 1998;72:141-196.

2. Robertson KD, Jones PA. DNA methylation: past, present and future directions. Carcinogenesis 2000;21(3):461467.

3. Shen L, Kondo Y, Guo Y, Zhang J, Zhang L, Ahmed S, et al. Genome-wide profiling of DNA methylation reveals a class of normally methylated CpG island promoters. PLoS Genet 2007;3(10):2023-2036.

4. Brait M, Sidransky D. Cancer epigenetics: above and beyond. Toxicol Mech Methods 2011;21(4):275-288.

5. Zhang FF, Morabia A, Carroll J, Gonzalez K, Fulda K, Kaur M, et al. Dietary patterns are associated with levels of global genomic DNA methylation in a cancer-free population. J Nutr 2011;141(6):1165-1171.

6. Supic G, Jagodic M, Magic Z. Epigenetics: a new link between nutrition and cancer. Nutr Cancer 2013;65(6):781-792.

7. Verma M, Rogers S, Divi RL, Schully SD, Nelson S, Joseph $\mathrm{Su}$ L, et al. Epigenetic research in cancer epidemiology: trends, opportunities, and challenges. Cancer Epidemiol Biomarkers Prev 2014;23(2):223-233.

8. Kanwal R, Gupta K, Gupta S. Cancer epigenetics: an introduction. Methods Mol Biol 2015;1238:3-5

9. Maio M, Covre A, Fratta E, Di Giacomo AM, Taverna P, Natali PG, et al. Molecular pathways: At the crossroads of cancer epigenetics and immunotherapy. Clin Cancer Res 2015;15,21(18):4040-4047. 